\title{
Germany remains split on animal testing
}

[MUNICH] A committee of the German parliament will this month begin work on a possible compromise between opposing factions who have been fighting over amendments to the 1986 animal protection law that were proposed last year by the cabinet.

The move follows the emergence of a new challenge to the work of German biologists, namely a proposal submitted last autumn by the opposition Social Democrat party (SPD) that the protection of animal rights should be enshrined in the constitution.

One of the main goals of the cabinet's proposal is to reduce the bureaucratic burden on scientists applying for licences for animal experiments.

The bill containing the amendments was approved by the Bundestag, the conservativedominated lower house, last November. But the Bundesrat, the upper house in which the SPD has a majority, rejected the bill. The opposition wants stricter controls on the handling of farm animals, and a clause requiring alternatives to animal experiments to be used wherever possible.

Germany's animal protection law is the strictest in the European Union (EU). Whereas in most countries scientists holding personal licences can conduct experiments according to their own timetables, German scientists have to apply for approval for each separate experiment.
Amendment to the German law has become necessary to bring it into line with new EU rules, and the government is keen to take the opportunity to introduce other changes to make life easier for researchers. One proposed change would give automatic approval to protocols that have not been formally approved within three months of submission to regional government offices (see Nature 385, 760; 1997).

Researchers have welcomed this proposal, pointing out that authorities hostile to animal research often draw out approval procedures for more than six months. Scientists argue that strict regulations threaten the international competitiveness of the life sciences in Germany. "Time is a decisive factor in science, while collaboration with international research groups demands flexibility," says Jean-Alice Büttner-Ennevener, a professor of neuropathology at the University of Munich.

But animal rights activists are dismayed at the proposed change. "This would be a big reversal of the achievements we have made in the past," says Jörg Styrie, scientific adviser of Bund gegen Mißbrauch der Tiere, the association opposing animal abuse.

In the current political climate, a compromise is unlikely before the federal elections in September. Nor is the proposed change to the constitution likely to be resolved soon. Demands by the SPD and the Greens that the protection of animal rights be included in constitutional law, alongside guarantees for the freedom of science and research, would make Germany the only country in Europe where animal welfare is a constitutional issue.

Constitutional changes require a twothirds majority in parliament, and no party or coalition is likely to achieve that in the foreseeable future. But researchers remain worried. "If animal protection became a constitutional matter, it would constantly clash with the constitutional freedom to research," says Janerik Bohling, spokesman of the Society of Health and Research, Germany's main research lobby group. And last week a local referendum voted in favour of the Bavarian government considering changes to the Bavarian constitution, including animal protection.

Academic and industrial researchers "could be driven out of Germany", says Bohling. The rights of scientists would have to be weighed up against the rights of animals during every licence approval, and challenges to the ethical status of experiments could end up in long battles in the constitutional courts.

The number of experimental animals used in Germany decreased by almost 50 per cent over the first half of the 1990s, to 1.6 million in 1995. According to the German centre for alternatives to animal testing, ZEBET, in Berlin, this is mainly due to progress in developing alternatives.

BarbaraMiller

\section{Science advice gets a face-lift in Australian reorganization}

[SYDNEY] Australia's chief scientist, John Stocker, has persuaded the Coalition government to revamp its scientific advisory mechanisms, has won greater influence for scientists over policy - and has managed to have his own job upgraded.

The changes follow recommendations by Stocker in a review carried out for the former science minister, Peter McGauran (see Nature 385, 473 \& 388, 8; 1997). The only proposal not accepted was one giving more influence to McGauran because he was not a member of cabinet. McGauran has since had to resign, and his portfolio was taken over by John Moore, already a cabinet minister.

The renamed Prime Minister's Science, Engineering and Innovation Council (PMSEIC) was originally formed under a Labor government in 1989. Stocker runs PMSEIC, which will become more powerful at the expense of the Australian Science and Technology Council (ASTEC). Stocker is responsible to both the Prime Minister, John Howard, and to Moore.

ASTEC, set up by a Coalition government 20 years ago, will be wound up later this year. On becoming chief scientist in late 1996, Stocker was made chairman of ASTEC, but

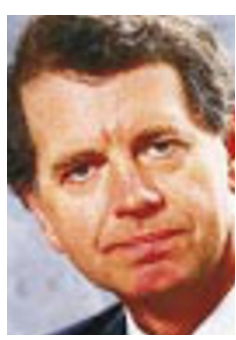

Stocker: ASTEC gives way to PMSEIC. concluded that it was not worth continuing. He describes its two-year 'Foresight' study, intended to define national priorities, as "wasted effort producing broad generalizations that couldn't be applied". The study was quietly buried.

Announcing the changes, Howard wrote

that the emphasis of the new council "reinforces the increasingly important role the government sees science and technology playing in Australia's future". He said that the 20 members of PMSEIC (seven ministers involved in science and technology, seven representatives of academies and universities and six individuals) will be augmented by "other key representatives of the business and scientific community".

Stocker wants to include the chairs of the two major research granting bodies, the Australian Research Council and the National Health and Medical Research Council. He acknowledges that, in recent years, meetings of the prime minister's council have been little more than " ad hoc briefings", from which no discernible changes to policy ensued.

In the new structure, the non-ministerial members will make up three working parties, taking over the role of ASTEC and charged with producing recommendations for policies and action. Stocker will chair the most important working group, on national priorities. "We aim to become a mainstream channel into policy... ASTEC could not plug into the prime minister," he says.

Topics that are politically sensitive following the government's cuts and increased charges in its first two budgets will not be avoided. The main working party's agenda includes the supply of a technologically trained workforce - science enrolments at universities have dropped markedly — and the support of basic research in universities, where infrastructure is under strain.

The full council will meet twice yearly. Stocker acknowledges pressure to deliver concrete proposals to its next meeting in mid-year, as that could be the last before a federal election.

Peter Pockley 